\title{
ECOLOGICAL ANALYSIS OF THE DENDROFLORA OF FUTOŠKI PARK IN THE CITY OF NOVI SAD
}

\author{
Aleksandar KURJAKOV, Jelena ČUKANOVIĆ, Milan BLAGOJEVIĆ, Emina MLADENOVIĆ, \\ Ksenija HIEL, Snežana VUKIĆEVIĆ ${ }^{1}$
}

Summary: The purpose of this paper is to analyze the floristic composition, abundance, biological spectrum and ecological effects of Futoški Park trees and shrubs on the basis of bioindicators. The field research was conducted in Futoški Park, which is one of the oldest and largest parks in the City of Novi Sad, covering an area of 81,306 $\mathrm{m}^{2}$. Upon determining the floristic composition of Futoški Park and the protection zone around the Park hotel, a total of 121 genotypes were recorded, out of which 34 species and lower taxa belong to the Gymnosperm phylum (Pinophyta) and 87 species and lower taxa belong to the Angiosperm phylum (Magnoliophyta). A total of 5,228 representatives of dendroflora were found. The biological range of trees and shrubs in the study area mostly includes deciduous nanophanerophytes (34.98\%) and evergreen nanophanerophytes (33.72\%), whereas the remainder includes evergreen phanerophytes (16.35\%) and the least prevalent deciduous phanerophytes (14.94\%). The analysis of ecological indices shows that the greatest number of species meet the environmental requirements, and are successfully acclimated to the climatic and soil conditions. On the basis of the overall vitality and ornamental features of the dendroflora analyzed, it can be argued that Futoški Park is a unique ecological and environmental entity in the urban structure of the city.

Key words: green spaces, park, adaptability, ecological index, life forms

\section{INTRODUCTION}

Green spaces are an important part of every city, contributing to its social, environmental and economic features (McPherson et al., 2005, Conway and Urbani, 2007, Escobedo et al., 2008). Of all the plants found in green spaces, trees and shrubs are the most useful in urban greenery (Ocokoljić et al., 2010). Vujković et al. (2003) emphasize that the richness of color and the variety of forms render urban green spaces irreplaceable in the composition of urban areas. The spatial composition of green areas is influenced by the following biological characteristics of species: size and shape, branching type, leaf color, flowers and fruits. Furthermore, environmental conditions such as climate, soil, relief and water greatly affect green spaces. Each plant species grow in a specific habitat, and is, to a greater or lesser extent, an indicator of habitat characteristics (Vujković et al., 2003, Anastasijević, 2007).

Urban parks are important for biodiversity conservation in the city. However, park vegetation is influenced by a number of stress factors caused by direct or indirect human influence (Lapaix, 2010, Ninić-Todorović et al., 2015). In order to improve the functionality of urban greenery, it is necessary to assess its condition, which is the first step towards the revitalization and preservation of green spaces (Stavretović et al., 2010).

The purpose of this paper is to analyze the floristic composition, abundance, biological spectrum and ecological effects of Futoški Park trees and shrubs on the basis of bioindicators.

\footnotetext{
${ }^{1}$ Aleksandar Kurjakov, MSc, Teaching assistant, Jelena Čukanović, PhD, assistant professor, Milan Blagojević, MSc, Emina Mladenović, PhD, assistant professor, Ksenija Hiel, assistant professor, Snežana Vukićević, MSc, University of Novi Sad, Faculty of Agriculture, Novi Sad,8 Dositeja Obradovića Sq.,21000 Novi Sad, Serbia.

• Corresponding author: Jelena Čukanović,e-mail: cukanovicj@polj.uns.ac.rs
} 


\section{MATERIAL AND METHODS}

The field research was conducted in Futoški Park, which is one of the oldest and largest parks in the City of Novi Sad, covering an area of $81,306 \mathrm{~m}^{2}$. Due to its biodiversity, exceptional old tree specimens, as well as cultural and historical characteristics, the park is placed under protection as a natural monument (Figure 1).

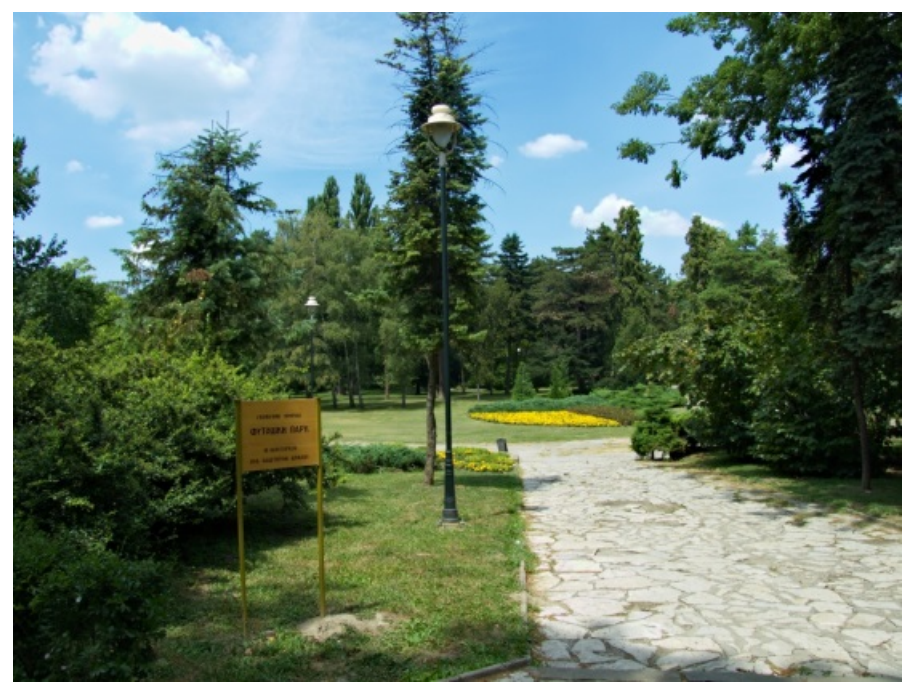

Figure 1. Futoški park in Novi Sad (Photo: Kurjakov A., 2011)

As part of the urban area of Novi Sad, Futoški park belongs to the temperate continental to continental climate (Katić et al., 1979). The site elevation is $78 \mathrm{~m}$, the mean annual temperature reaches $11.1^{\circ} \mathrm{C}$ and the mean annual precipitation amounts to $603.1 \mathrm{~mm}$ (Obrknežev et al., 2009).

Based on the land classification of Yugoslavia (Škorić et al., 1985), Futoški park is one of the hydromorphic fluvial soil types - humofluvisol. Park's dendoflora, with willows and poplars predominating, plays an important role in the phytoremediation of heavy metals in the soil. Chemical analyses of the soil indicate a low concentration of heavy metals (Ninić-Todorović et al., 2008).

Due to physiological constraints, plants have the ability to grow in their natural environment under certain conditions. Indicator values are used to characterize these conditions. The ecological index represents the interaction between plants and the most important ecological factors. The following ecological indices, used in this analysis, are defined by Landolt (1977): plant moisture requirements (F), exchange reactions in soil (R), the content of nitrogen compounds and nitrogen $(\mathrm{N})$, the content of humus, i.e. organo-mineral complexes $(\mathrm{H})$, substrate dispersion/aeration (D), salinity (S), light regime (L), temperature (T) and continentality (K). The values of ecological indices are expressed on a scale from 1 to 5 , where 1 denotes minimum and 5 maximum requirements. A percentage share has been determined for all the ecological indices studied relative to the number of individuals and the index given. Furthermore, the dominant ecological indices were established alongside the mean value of every index, which was calculated as the sum of ecological index values for all individuals, divided by the total number of individuals in a given area.

The growth and life forms were determined on the basis of the position of winter buds (Raunkiaer, 1934). The groups were formed analogous to those of Ellenberg's (1974) and marked alphabetically in the following manner: p deciduous phanerophytes, $\mathrm{i}$ - evergreen phanerophytes, $\mathrm{n}$ - deciduous nanophanerophytes, and $\mathrm{j}$ - evergreen nanophanerophytes.

\section{RESULTS}

Upon determining the floristic composition of Futoški Park and the protection zone around the Park hotel, a total of 121 genotypes were recorded, out of which 34 species and lower taxa belong to the Gymnosperm phylum (Pinophyta) and 87 species and lower taxa belong to the Angiosperm phylum (Magnoliophyta). A total of 5,228 representatives of dendroflora were found (Table 1). 
Table 1. Number of dendroflora individuals in Futoški Park

\begin{tabular}{|c|c|}
\hline Dendroflora forms & Number of individuals \\
\hline Deciduous trees & 800 \\
\hline Evergreen trees & 811 \\
\hline Deciduous shrubs & 1,803 \\
\hline Evergreen shrubs & 1,814 \\
\hline TOTAL & 5,228 \\
\hline
\end{tabular}

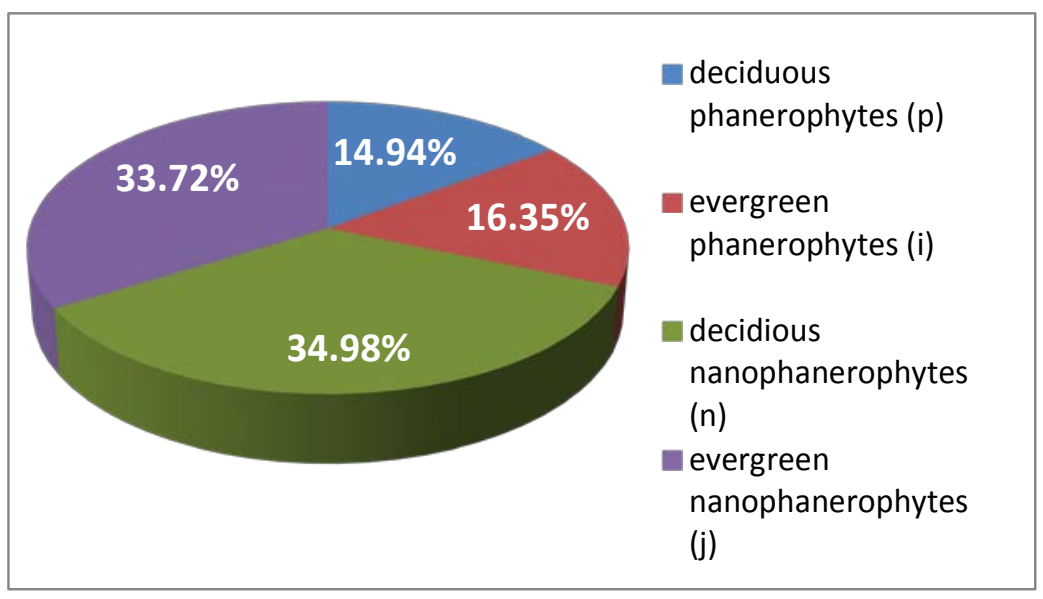

Figure 1. Raunkiaer plant life forms (W) in Futoški Park

The biological range of trees and shrubs in the study area (Figure 1) mostly includes deciduous nanophanerophytes (34.98\%) and evergreen nanophanerophytes (33.72\%), whereas the remainder includes evergreen phanerophytes (16.35\%) and the least prevalent deciduous phanerophytes (14.94\%).

Figure 2. Average values of dendroflora ecological indices in Futoški Park 
Table 2. Ecological analysis of the dendroflora in Futoški Park

\begin{tabular}{|c|c|c|c|}
\hline $\begin{array}{l}\text { Ecological index and the average value of } \\
\text { ecological index }\end{array}$ & $\begin{array}{c}\text { Value of } \\
\text { ecological } \\
\text { index }\end{array}$ & $\begin{array}{l}\text { No. of species/ No. } \\
\text { of individuals }\end{array}$ & $\begin{array}{l}\text { Percentage of specimens with a } \\
\text { given index in the total number } \\
\text { of individuals (\%) }\end{array}$ \\
\hline \multirow{8}{*}{$\begin{array}{l}\mathrm{F}^{*}-\text { habitat humidity } \\
\qquad(\mathrm{F}-2,64)\end{array}$} & 1 & $6 / 129$ & $2.47 \%$ \\
\hline & 2 & $30 / 1663$ & $31.81 \%$ \\
\hline & $2 \mathrm{w}$ & $2 / 73$ & $1.40 \%$ \\
\hline & 3 & 64 / 3059 & $58.51 \%$ \\
\hline & $3 \mathrm{w}$ & $2 / 37$ & $0.71 \%$ \\
\hline & 4 & $14 / 137$ & $2.62 \%$ \\
\hline & $4 \mathrm{w}$ & $1 / 2$ & $0.04 \%$ \\
\hline & $\mathrm{x}$ & $2 / 128$ & $2.45 \%$ \\
\hline \multirow{5}{*}{$\begin{array}{l}\mathrm{R} \text { - environmental chemical reaction } \\
\qquad(\mathrm{R}-3,31)\end{array}$} & 2 & $7 / 104$ & $1.99 \%$ \\
\hline & 3 & 62 / 3312 & $63.35 \%$ \\
\hline & 4 & $42 / 1601$ & $30.62 \%$ \\
\hline & 5 & $3 / 36$ & $0.69 \%$ \\
\hline & $\mathrm{x}$ & $7 / 175$ & $3.35 \%$ \\
\hline \multirow{3}{*}{$\begin{array}{l}\mathrm{N} \text { - nitrogen content and nitrogen compounds } \\
\qquad(\mathrm{N}-2,90)\end{array}$} & 2 & $27 / 1218$ & $23.30 \%$ \\
\hline & 3 & $61 / 3309$ & $63.29 \%$ \\
\hline & 4 & $33 / 701$ & $13.41 \%$ \\
\hline \multirow{4}{*}{$\begin{array}{l}\mathrm{H} \text { - content of organo-mineral compounds } \\
\qquad(\mathrm{H}-3,02)\end{array}$} & 2 & $10 / 287$ & $5.49 \%$ \\
\hline & 3 & 79 / 4439 & $84.91 \%$ \\
\hline & 4 & $29 / 371$ & $7.10 \%$ \\
\hline & $\mathrm{x}$ & $3 / 131$ & $2.51 \%$ \\
\hline \multirow{6}{*}{$\begin{array}{l}\text { D - dispersion/aeration of the substrate } \\
\text { (D - 3,57) }\end{array}$} & 1 & $1 / 71$ & $1.36 \%$ \\
\hline & 2 & $8 / 295$ & $5.64 \%$ \\
\hline & 3 & $32 / 1356$ & $25.94 \%$ \\
\hline & 4 & 69 / 3260 & $62.36 \%$ \\
\hline & 5 & $3 / 20$ & $0.38 \%$ \\
\hline & $\mathrm{X}$ & $8 / 226$ & $4.32 \%$ \\
\hline \multirow{2}{*}{ S - salinity } & + & $2 / 3$ & $0.06 \%$ \\
\hline & - & 0 & 0 \\
\hline \multirow{5}{*}{$\begin{array}{l}\mathrm{L}-\text { light regime } \\
\quad(\mathrm{L}-3,22)\end{array}$} & 1 & $4 / 32$ & $0.61 \%$ \\
\hline & 2 & $20 / 397$ & $7.59 \%$ \\
\hline & 3 & $54 / 3179$ & $60.81 \%$ \\
\hline & 4 & $41 / 1605$ & $30.70 \%$ \\
\hline & 5 & $2 / 15$ & $0.29 \%$ \\
\hline \multirow{4}{*}{$\begin{array}{l}\mathrm{T} \text { - temperature } \\
(\mathrm{T}-4,42)\end{array}$} & 2 & $5 / 55$ & $1.05 \%$ \\
\hline & 3 & $28 / 635$ & $12.15 \%$ \\
\hline & 4 & $57 / 1583$ & $30.28 \%$ \\
\hline & 5 & $31 / 2955$ & $56.52 \%$ \\
\hline \multirow{4}{*}{$\begin{array}{l}\mathrm{K} \text { - continentality } \\
\quad(\mathrm{K}-2,70)\end{array}$} & 2 & 39 / 2453 & $46.92 \%$ \\
\hline & 3 & 47 / 1955 & $37.39 \%$ \\
\hline & 4 & $31 / 733$ & $14.02 \%$ \\
\hline & 5 & $4 / 87$ & $1.66 \%$ \\
\hline
\end{tabular}

*In addition to the ecological index F, w tag closely describes plants that develop in habitats with variable humidity

\section{DISSCUSION}

By analyzing the ecological indices of Futoški Park dendroflora (Figure 2, Table 2), the following relationships were established:

The ratio of plants to habitat humidity (F). By analyzing the environmental index of humidity, one can conclude that mesophytes dominate, which indicates a habitat with medium humidity (an $F_{3}$ index of 59.22\% (3,096 individuals). Only $0.71 \%$ of the individuals recorded occur in habitats that vary in moisture.

With an $\mathrm{F}_{2}$ index of 33.21\%, subxerophytes follow mesophytes, indicating a relatively dry habitat. Only 2.66\% of individuals are hygrophytes, with an index of $\mathrm{F}_{4}$ and $\mathrm{F}_{4 \mathrm{~W}}$, and $2.47 \%$ of individuals (129 plants) were xerophytes, with an index of $F_{1}$. The average value of the ecological index of soil moisture is 2.64 , which indicates mesophytes 
predominate. Only a small percentage of plants are indicators of extremely dry habitats, which coincides with the annual sum of precipitation of $603.1 \mathrm{~mm}$ (the park has no artificial irrigation systems).

The ratio of plants to environmental chemical reactions - pH (R). By analyzing the index of environmental chemical reactions, the predominance of neutrophilic plants was confirmed, which indicates a neutral to slightly acidic habitat $\left(\mathrm{R}_{3}-63.35 \%\right.$, 3,312 individuals). The indicators of neutral to slightly alkaline environment ( $\mathrm{R}_{4}-$ $30.62 \%, 1,601$ individuals) follow. Only $1.99 \%$ of the plants are indicators of the acidic environment $\left(\mathrm{R}_{1}\right)$, while only 36 species of the plants are indicative of the base environment $\left(R_{5}-0.69 \%\right)$. There were no acidophilic plants recorded in the study area, which would indicate an extremely acidic environment. In addition to the above mentioned, the average value of the index of environmental chemical reactions (R) was 3.31, which is also in accordance with the previous $\mathrm{pH}$ value of 7.47 measured in the parkland (in $1 \mathrm{M} \mathrm{KCl)} \mathrm{(Ninić-Todorović} \mathrm{et} \mathrm{al.,}$ 2008).

The ratio of plants to nitrogen content and nitrogen compounds $(N)$. By analyzing the ecological indices of nitrogen content and nitrogen compounds in the soil, it can be argued that the most common individuals are those with an $\mathrm{N}_{3}$ index of $63.29 \%$ and an $\mathrm{N}_{2}$ index of $23.30 \%$, i.e. the indicators of mesotrophic and oligotrophic systems. The species indicators of eutrophic systems are present in a smaller share accounting for $13.41 \%\left(\mathrm{~N}_{4}\right)$. The park has no distinct indicators of oligotrophic systems $\left(\mathrm{N}_{1}\right)$, nor distinct indicators of eutrophic systems $\left(\mathrm{N}_{5}\right)$. The mean value of this index is 2.90, which also indicates an environment with moderate content of nitrogen compounds. This is in accordance with the previous results by Ninić-Todorović et al. (2008), who found that the content of nitrogen and nitrogen compounds in the park soil was $0.221 \%$.

The ratio of plants to the content of organo-mineral compounds (humus) $(\mathrm{H})$. Regarding the content of humus in the park, there is a predominance of indicators of the habitat with a medium humus content $\left(\mathrm{H}_{3}-84.91 \%\right.$, 4,439 individuals). To a lesser extent, there are individuals which are the indicators of a rich humus content $\left(\mathrm{H}_{4}-7.10 \%\right)$ and a low humus content $\left(\mathrm{H}_{2}-5.49 \%\right)$. In the study area, there are also individuals which can thrive in both rich and poor soils (x), accounting for $2.51 \%$. There were no plants with non-humic indicators of habitat $\left(\mathrm{H}_{1}\right)$, nor exclusive indicators of humichabitats $\left(\mathrm{H}_{5}\right)$. The average value of the ecological index is 3.02, which confirms the fact that Futoški Park is the habitat with a medium humus content, which was confirmed in the previous research by NinićTodorović et al. (2008).

The ratio of plants according to the dispersion / aeration environment (D). Most of the park individuals belong to a group that lives in moderately aerated habitats $\left(\mathrm{D}_{4}-62.36 \%, 3,260\right.$ plants). Those are followed by individuals that grow in well-aerated habitats $\left(\mathrm{D}_{3}-25.94 \%\right)$ and plants living in habitats where the particle diameter in the root zone exceeds $2 \mathrm{~mm}\left(\mathrm{D}_{2}-5.64 \%\right)$. Plants that do not choose the dispersion area (x) and can equally grow in underdeveloped and poorly aerated soils are represented by $4.32 \%$. Only a small number of individuals inhabit poorly aerated soils $\left(D_{1}-1.36 \%, D_{5}-0.38 \%\right)$. The average index value of dispersion/aeration (D - 3.57) characterizes the area as a habitat with good to moderately aerated land. Humofluvisol occurs as the first stage in the further development of recent alluvial deposits, mainly loamy and of clay composition as an independent type of the genetic material profile ACG.

The ratio of plants to salinity (S). The absolute predominance of individuals intolerant to an increased content of $\mathrm{Na}+$ ions and the presence of only two species and three individuals tolerant to elevated contents of $\mathrm{Na}+$ ions indicate a salt-free surface of the study area.

The ratio of plants to habitat light $(L)$. The largest number of individuals in the park belong to semi- sciophytes, which are indicators of half-shadowed areas ( $\mathrm{L}_{3}-60.81 \%, 3179$ plants). Semi-sciophytes are followed by the group of plants between semi-sciophytes and heliophytes $\left(\mathrm{L}_{4}-30.70 \% 1605\right.$ plants). Indicators of shadowy habitats are represented by 397 plants ( $\left.\mathrm{L}_{2}-7.59 \%\right)$. Only 32 plants belong to the distinct indicators of shadows - sciophytes $\left(\mathrm{L}_{1}\right.$ $0.61 \%$ ), while 15 plants, or $0.29 \%$, to heliophytes $\left(L_{5}\right)$. The average value of this index is 3.22 , which supports a medium-thick arrangement of the plants in the park.

The ratio of plants to the habitat's temperature $(\boldsymbol{T})$. In relation to the ecological index of temperature, extremely thermophilic plants, i.e. indicators of the warmest habitats $\left(\mathrm{T}_{5}-56.52 \%\right)$, are discernible. Thermophilic plants are slightly less represented with a total of 1,583 individuals $\left(\mathrm{T}_{4}-30.28 \%\right)$. They are followed by mesotherm plants $\left(\mathrm{T}_{3}\right)$ with a share of $12.15 \%$, and only 55 plants belong to the transitional group between psychrophilic and mesotherm plants $\left(\mathrm{T}_{2}-1.05 \%\right)$. In the studied area, plant indicators of very cold habitats $\left(\mathrm{T}_{1}\right)$ were not found. The average value of the ecological index of temperature is 4.42 .

The ratio of plants to continentality $(K)$. The value of the ecological index of continentality entails adjusting certain plant species to the climatic conditions of the area. The most dominant plants in the park are the ones that are favorable for the conditions of sub-oceanic climate $\left(\mathrm{K}_{2}\right)$, accounting for $46.92 \%$. Furthermore, the most numerous plants are those living in extra-continental areas $\left(\mathrm{K}_{3}\right)$, accounting for $37.39 \%$. Plants that inhabit the temperate continental climate $\left(\mathrm{K}_{4}\right)$ occupy a share of $14.02 \%$, and only $1.66 \%$ of the plants belong to the group that lives exclusively in continental climatic areas $\left(\mathrm{K}_{5}\right)$. Plants that occur only in the oceanic climate $\left(\mathrm{K}_{1}\right)$ were not recorded. 
The average value of $\mathrm{K}$ index is 2.70 . Given the relatively good viability of most exotic species, it can be concluded that the exotics are well-acclimatized to the temperate continental climate that prevails in the park.

Based on the ecological analysis of Futoški Park dendroflora, some species characterized by exceptional biological, decorative and reproductive value can be distinguished, e.g. the Turkish hazel (Corylus colurna L.) with a population of 54 individuals. The oldest specimens of Turkish hazel in the area of Novi Sad are 4 trees in Futoški Park near the Park hotel, aged about 110 years. The trees are of extremely high visual and aesthetic value, with straight trunks and pyramidal crowns of whorl-spaced branches. California incense cedar (Libocedrus decurrens Torr.) is a non-indigenous conifer native to the western parts of North America. Only in Futoški Park, there are four older specimens that are of high functional value and the immense importance to the mass-reproduction of seeds in cycles of two years. Bald cypress (Taxodium distichum (L.) Rich.), old pedunculate oak (Quercus robur L.) and two individuals of European White Elm (Ulmus effuse Willd.) constitute an added value of Futoški park. The oldest ginkgo (Ginkgo biloba L.) individual in Novi Sad is located in front of the Park hotel entrance.

\section{CONCLUSION}

The richness of Futoški Park consists of 121 taxa (species, varieties and forms) of woody flora with spatial and compositional arrangements in the form of small groups, masses, alleys and individual tree skyscrapers. Many exotic species are grown exclusively in this area.

The analysis of ecological indices shows that the greatest number of species meet the environmental requirements, and are successfully acclimated to the climatic and soil conditions. On the basis of the overall vitality and ornamental features of the dendroflora analyzed, it can be argued that the park is a unique ecological and environmental entity in the urban structure of the city.

\section{REFERENCES}

ANASTASIJEVIĆ, N.: Podizanje i negovanje zelenih površina. Šumarski fakultet, Univerzitet u Beogradu, Beograd, 2007. CONWAY, T. M., URBANI, L.: Variations in municipal urban forestry policies: A case study of Toronto, Canada. Urban Forestry \& Urban Greening, 6(3)181-192, 2007.

ellenberg, H.: Zeigerwerte der Gefäßpflanzen Mitteleuropas. Scripta Geobotanica, 9:1-97, 1974.

ESCOBEDO, F.J., WAGNER, J.E., NOWAK, D.J., LUZ DE LA MAZA, C., RODRIGUEZ, M., CRANE, D.E.: Analyzing the coast effectiveness of Santiago, Chile's policy of using urban forests to improve air quality. Journal of Environmental Management, 86 (1)148-157, 2008.

KATIĆ, P., ĐUKANOVIĆ, D., ĐAKOVIĆ, P.: Klima AP Vojvodine. Poljoprivredni fakultet u Novom Sadu - OOUR Institut za ratarstvo i povrtarstvo, Jugoslavija, Novi Sad,1979.

LANDOLT E.: Ökologische Zeigerwerte zur Schweizer Flora (Ecological Indicator Values of Swiss Flora). Publications of Geobotanical Institute of the Swiss Federal Faculty of Technology, Rübel Foundation, Switzerland, Zürich,1977.

LAPAIX, R., FREEDMAN, B.: Vegetation Structure and Composition within Urban Parks of Halifax Regional Municipality, Nova Scotia, Canada. Landscape and Urban Planning, 98 (2)124-135, 2010.

MCPHERSON E.G., SIMPSON, J.R., PEPER, P., MACO, S.E., XIAO, Q.: Municipal forest benefits and costs in five US cities. Journal of Forestry, 103 (8)411-416, 2005.

NINIĆ-TODOROVIĆ J., NEŠIĆ LJ., LAZOVIĆ R., KURJAKOV A.: Futoški park kao zaštićeni spomenik prirode. Letopis naučnih radova, 32 (1)102-110, 2008.

NINIĆ-TODOROVIĆ J., OCOKOLJIĆ, M.,TODOROVIĆ, I., ČUKANOVIĆ, J., SENTIĆ, I., KURJAKOV, A., ŽUGIĆ, E.: Urban stress tolerance evergreen trees on green areas of Novi Sad city. Contemporary agiculture, 64, (1-2) 20-26, 2015.

OBRKNEŽEV, R., GAČEVIĆ, R., BURSAĆ, T., GRUJIĆ, Z., JOVKOVIĆ, M., PANJOVIĆ, A., MARKOVIĆ, V., ŠEŠUM, M., LETIĆ, M., PAUNIĆ, M., VUJKOV, B., KOVAČEVIĆ, M.: Studija zaštite životne sredine na području Novog Sada. Javno preduzuće "Urbanizam", Zavod za urbanizam, Novi Sad, 2009.

OCOKOLJIĆ, M., MEDAREVIĆ, M., NIKIĆ, Z., GALEČIĆ, N., STOJIČIĆ, Đ.: Variability of features in half-sib posterity as a basis in plant breeding of the species Koelreuteria paniculata Laxm. Biological Sciences, Belgrade, 62(3)693-703, 2010.

RAUNKIAER, C.:The Life Forms of Plants and Statistical Plant Geograph. Oxford University Press, Oxford, 1934.

STAVRETOVIĆ, N., VUČKOVIĆ, M., STAJIĆ, B.: Classification of trees and tree species in Obrenovac "Mali park" by elements of growth, vitality and ornamentalness. Biological Sciences, Belgrade, 62 (4) 1119-1024, 2010.

ŠKORIĆ A., FILIPOVSKI G., ĆIRIĆ M.: Klasifikacija zemljišta Jugoslavije. Akademija nauka i umjetnosti Bosne i Hercegovine, Posebna izdanja, knjiga LXXVIII, Jugoslavija,Sarajevo, 1985.

VUJKOVIĆ, LJ., NEĆAK, M., VUJIČIĆ, D.: Tehnika pejzažnog projektovanja. Šumarski fakultet, Univerzitet u Beogradu, Jugoslavija, Beograd, 2003. 


\title{
EKOLOŠKA ANALIZA DENDROFLORE FUTOŠKOG PARKA U NOVOM SADU
}

\author{
Aleksandar KURJAKOV, Jelena ČUKANOVIĆ, Milan BLAGOJEVIĆ, Emina MLADENOVIĆ, Ksenija HIEL, \\ Snežana VUKIĆEVIĆ
}

Izvod: Cilj rada je analiza florističkog sastava, biološki spektar i ekološka analiza na osnovu vrednosti bioindikatora drveća i žbunja na području Futoškog parka u Novom Sadu. Futoški park je jedna od najstarijih i najvećih parkovskih površina na području grada Novog Sada koji se prostire na površini od $81306 \mathrm{~m}^{2}$. Snimanjem florističkog sastava parka, uključujući i zaštitnu zonu oko hotela "Park", ustanovljeno je prisustvo 121 genotipa, od kojih 34 vrsta i nižih taksona iz odeljka golosemenica (Pinophyta), a 87 vrsta i nižih taksona iz odeljka skrivenosemenica (Magnoliophyta). Ukupno je evidentirano 5228 predstavnika dendroflore. Dendrofloru istraživanog lokaliteta u najvećem procentu čine listopadne (34,98\%) i zimzelene nanofanerofite (33,72\%), dok ostatak pripada zimzelenim (16,35\%) i listopadnim fanerofitama (14,94\%) Analiza ekoloških indeksa pokazala je da najveći broj vrsta ispunjava zahteve okruženja i da su uspešno aklimatizovane na postojeće klimatske i zemljišne uslove. Na osnovu celokupne dekorativnosti i vitalnosti analizirane dendroflore ustanovljeno je da Futoški park čini jedinstven ekološki i okružujući entitet u urbanoj strukturi grada

Ključne reči: zeleni prostori, park, adaptabilnost, ekološki indeks, životne forme

Received / Primljen: 19.01.2017. Accepted / Prihvaćen: 04.07.2017. 